\title{
Tracking macroalgae introductions in North Atlantic oceanic islands
}

\author{
Joana Micael $\cdot$ Manuela I. Parente $\cdot$ \\ Ana C. Costa
}

Received: 3 December 2013/Revised: 21 January 2014/Accepted: 25 January 2014/Published online: 7 February 2014

(c) Springer-Verlag Berlin Heidelberg and AWI 2014

\begin{abstract}
The Azores archipelago was selected as a case study since there are few studies on macroalgae introduction in oceanic islands. While at a global scale, around $3 \%$ of macroalgae are considered non-indigenous; in the remote oceanic islands of the Azores, over $6 \%$ of the marine algal flora is non-indigenous. The taxa distribution pattern of non-indigenous species in the Azores is significantly different from the distribution pattern in the globe. The most representative group was Rhodophyta species, being $84 \%$ of the total non-indigenous macroalgae, mainly introduced via maritime traffic. This study highlights the vulnerability of remote islands to the introduction of macroalgae and the need to develop further studies on other archipelagos to understand whether the observed vulnerability is generally characteristic of oceanic islands. The development of local monitoring and mitigation programs and the necessity of regulatory and preventive measures for the maritime traffic vector are strongly suggested.
\end{abstract}

Keywords Macroalgae $\cdot$ Maritime traffic $\cdot$ Nonindigenous species $\cdot$ Remote islands $\cdot$ Taxonomic pattern

Communicated by F. Weinberger.

Electronic supplementary material The online version of this article (doi:10.1007/s10152-014-0382-7) contains supplementary material, which is available to authorized users.

J. Micael $(\bowtie) \cdot$ M. I. Parente · A. C. Costa CIBIO, Centro de Investigação em Biodiversidade e Recursos Genéticos, InBIO Laboratório Associado, Pólo dos Açores, Universidade dos Açores, 9501-801 Ponta Delgada, Portugal e-mail: jfmicael@yahoo.com

\section{Introduction}

Macroalgae introductions have been extensively reviewed in the last three decades, especially in the Mediterranean Sea (e.g., Verlaque 1994; Verlaque 2001; Boudouresque and Verlaque 2002; Ribera-Siguan 2002; Klein et al. 2005; Tsiamis et al. 2008; Galil 2009). Although a broad European geographical area was covered by Wallentinus (2002), other studies focus on specific geographical regions in the Atlantic Ocean such as the UK (e.g., Farnham 1980; Minchin 2007), Denmark (e.g., Thomsen et al. 2007), Canada (e.g., Chapman et al. 2002) and Florida (e.g., Jacoby et al. 2004). Specific studies in the Pacific Ocean include California (e.g., Jousson et al. 2000), Mexico (e.g., Miller et al. 2011), Chile (e.g., Castilla et al. 2005), New Zealand (Nelson 1999) and Australia (e.g., Pollard and Hutchings 1990; Lewis 1999; Hewitt et al. 2004). Ruiz et al. (2000) investigated non-indigenous marine invertebrates and algae of the Pacific and Atlantic North America, evaluating some of the emergent patterns and underlying mechanisms of marine invasion. Recently, a global review on macroalgae introductions was reported by Williams and Smith (2007). Nevertheless, to the authors' knowledge, Smith et al. (2002) was the only study specifically targeting non-indigenous macroalgae on oceanic islands, focusing on the five most successful non-indigenous algae in Hawaii.

The uniqueness of oceanic islands with marine introductions is related to the degree of isolation of their shallow-water marine ecosystems, i.e., they are distant from colonization sources. In general, marine ecosystems on oceanic islands are characterized by: (1) small numbers of native species, with a reduced level of competition and few predator species; (2) a small population that is subject to demographic isolation; and (3) limited resources, such as food and space. As a result, oceanic islands are generally 
poor in species, exhibit simpler trophic webs and have a lower functional diversity than similar mainland ecosystems (Vitousek 1990). The biotic resistance of marine oceanic islands to introduced invaders is therefore limited, and the availability of empty niches is high (Pearson 2009).

Although marine invasions have occurred through time, such as punctuated events in geological time (e.g., changes in climate and dispersal barriers or catastrophic occurrences, see Ruiz and Hewitt 2008), at present a high percentage of biological invasions have a human-mediated origin (Wonham and Carlton 2005). Often, even in cases where invasion was considered to be a natural event, it was subsequently assessed that the expansion was probably due to changes in habitat structuring caused by human intervention (McCulloch and Stewart 1998).

The Azores archipelago is located between latitudes $36^{\circ} 55^{\prime}$ and $39^{\circ} 43^{\prime}$ North and longitudes $24^{\circ} 46^{\prime}$ and $31^{\circ} 16^{\prime}$ West, at the northern edge of the North Atlantic subtropical gyre - the rotor of the North Atlantic circulation (Bashmachnikov et al. 2004). This North Atlantic archipelago comprises nine strongly isolated islands of recent volcanic origin (ages range between 0.3 and 8 million years), which spread over more than $600 \mathrm{~km}$ along a northwest-southeast axis (França et al. 2003). The Azores are set apart about $800 \mathrm{~km}$ from the archipelago Madeira, 1,500 km from the west coast of Europe and 1,900 km from the east coast of America, across the Mid-Atlantic Ridge (Coutinho et al. 2009). Sea surface temperatures have an annual range between 14 and $23{ }^{\circ} \mathrm{C}$. Tidal amplitudes range from 0.1 to $1.1 \mathrm{~m}$, mediated by the proximity of these islands to the North Atlantic amphidromic point and the absence of complicating continental margins (Ramos et al. 2012). The biogeographically mixed origin of the algal flora characteristic of the Azorean shores (Neto 1997) and the geographical position of the archipelago produce an algal flora on the Azores, which is important for natural heritage and that needs to be preserved.

The aim of this study is to contribute to a better understanding of the vulnerability of oceanic islands to macroalgae introductions through the identification of non-indigenous species (NIS) of macroalgae on the Azores archipelago and assessment of their invasive potential. The taxonomic distribution pattern of NIS on the Azores was contrasted with the known global distribution pattern of algae, in order to reveal possible differences between oceanic islands and continental coasts. Vectors of introduction, invasion status, establishment success and the functional group of NIS of macroalgae were discriminated as a strategy to develop robust management plans. Azores islands were chosen for this case study because of the ecological importance of this archipelago, representing an important geographical link between the NE Atlantic and NW Atlantic coasts (Morton et al. 1998). To the authors' knowledge, the vulnerability of oceanic islands to macroalgae introductions has not yet been addressed in the context of marine introductions.

\section{Methods}

The list of algal species of the Azores by Parente (2010) was used as the basis for this work, updated with additional species from recent publications (such as: Rosas-Alquicira et al. 2011; Wallenstein et al. 2010; Wallenstein 2011; León-Cisneros et al. 2012). Records of non-indigenous and cryptogenic species of the Azores were compiled from a wide variety of sources, mainly from literature searches through scientific papers and reports, including recent field and taxonomic studies, and supplemented with existing databases. Information on global algae distribution was taken from works such as Wallentinus (2002) and Nyberg and Wallentinus (2005), for European marine algae, and Goulletquer et al. (2002), for Atlantic marine algae. A chisquared goodness-of-fit test $(\chi 2)$ was used to assess if the known global taxonomic distribution pattern of macroalgal NIS was similar to the Azores macroalgal NIS taxonomic pattern (based on the number of species per taxonomic group).

Subsequently, we discriminated species based on a set of different variables considered important to assess the invasive potential of a species. They were the following: (a) origin; (b) vector of transportation and possible route of entry to the Azores; (c) population status; (d) relative density; (e) functional density; (f) invasive potential. These parameters are further described below.

Origin (native, non-indigenous and cryptogenic species status)

In this study, the International Union for Conservation of Nature (IUCN 2000), definition of "native" (indigenous) was adopted, i.e., a species, subspecies or lower taxon occurring within its natural range and dispersal potential.

In contrast, a "non-indigenous" species was defined as a species that has been intentionally or unintentionally introduced beyond its native range through human activities (Rosenthal 1980; Carlton 1985; Williamson and Fitter 1996; Eno et al. 1997; Williams and Smith 2007). In this study, a species that lacks geographical contiguity with its native range and/or is associated with introduction vectors or pathways (e.g., occurring in ship fouling or ballast water) is considered as "non-indigenous species" (Supplemental Table 1). The classification as a "non-indigenous species" was confirmed through reference to the literature. 
Table 1 The different variables considered important to assess the invasive potential of a species and respective categories

\begin{tabular}{|c|c|c|c|c|c|c|}
\hline \multirow{2}{*}{$\begin{array}{l}\text { Variables } \\
\text { Native origin } \\
\text { (5) }\end{array}$} & \multicolumn{6}{|l|}{ Categories } \\
\hline & NE Atlantic & & W Atlantic & Indian Ocean & Indo-Pacific & Pacific \\
\hline $\begin{array}{l}\text { Vector } \\
\text { (3) }\end{array}$ & \multicolumn{3}{|l|}{ Unknown } & Maritime traffic ${ }^{\mathrm{a}}$ & \multicolumn{2}{|c|}{ Fouling (within maritime traffic) ${ }^{\mathrm{b}}$} \\
\hline $\begin{array}{l}\text { Status } \\
(3)\end{array}$ & \multicolumn{3}{|l|}{ Not established } & Undetermined & \multicolumn{2}{|l|}{ Established } \\
\hline $\begin{array}{l}\text { Relative density } \\
\text { (6) }\end{array}$ & Rare & Occasional & Frequent & Abundant & Dominant & Unknown \\
\hline $\begin{array}{l}\text { Functional group } \\
\text { (5) }\end{array}$ & Filamentous & Corticated & Siphonous & Foliose & Corticated foliose & Articulated calcareous \\
\hline $\begin{array}{l}\text { Invasive potential } \\
\text { (3) }\end{array}$ & \multicolumn{3}{|l|}{ Not invasive } & Unknown & \multicolumn{2}{|l|}{ Invasive } \\
\hline
\end{tabular}

In parentheses is the number of categories considered for each variable

${ }^{a}$ Maritime traffic includes ballast water, hull fouling, sediments in ballast tanks, sediments attached to anchors/chains, commercial fishing nets and gear

${ }^{b}$ Fouling is considered as a subcategory of maritime traffic

Cryptogenic species, i.e., species for which the origin remains unknown, with no definite evidence of their native or introduced status according to Carlton (1996), although reported in the present work, are tabulated separately (Supplemental Table 2) and were excluded from the analyses. The status of some of these species as cryptogenic may change as knowledge of their dispersal mechanisms increases, or when studies with genetic markers allow the origin to be inferred.

To assess patterns of the native ranges of introduced species, five broad geographical regions were defined based on oceanic regions. These are NE Atlantic, W Atlantic, Indian Ocean, Indo-Pacific and Pacific Ocean (see Table 1).

\section{Transportation vectors}

There are numerous ways in which human activity results in the introduction of non-indigenous marine species. Although it is not always possible to determine the vector of introduction, the dominant vectors of non-indigenous marine species are maritime traffic and aquaculture (Rilov and Crooks 2009). There is little aquaculture in the Azores. To date, only one bivalve species (Venerupis decussata) has been introduced for commercial exploitation in the archipelago. Thus, the majority of introduced species appear to be associated with ship traffic. This study examined the most probable vectors for the introduction of a given species based on the literature and communication with scientific peers (e.g., HELCOM 2008). For some species, many transfer mechanisms are possible, making a specific vector difficult to assign. Two broad categories of vectors were distinguished: known, that is maritime traffic (including ballast water, hull fouling and sediments in ballast tanks, sediments attached to anchors/chains, commercial fishing nets and gear) and unknown (see Table 1). A subcategory of maritime traffic was also consideredfouling.

Population status (success of non-indigenous species)

The establishment of an introduced species is generally related to the survival of the individuals that initially arrive, and their capacity to reproduce and expand their population. Establishment is influenced both by the characteristics of the introduced individuals, as well as the receiving ecosystems (Rilov and Crooks 2009). Population status was determined based on literature data. A species was considered as established when there were multiple records. A species was considered as not established when there was a historical record, but the species could later not again be detected in the location where it had been identified or in any other location. The population status was considered as unknown for introduced species with a single record and where there was no prior surveying.

Relative density

Whenever information could be retrieved from the literature, the relative density of each species in the Azores was adapted from the DAFOR scale, an internationally recognized semi-quantitative scale by Sutherland (2006), which estimates frequency, categorizing species as follows: 
Dominant $>75 \%$; Abundant $50-75 \%$; Frequent $25-50 \%$; Occasional 5-25\%; Rare $<5 \%$ (see Table 1).

Functional group

As pointed out by Williams and Smith (2007), the success of introduced algae may be related to their functional group. Six functional groups, based on algal anatomical and morphological characteristics (see Table 1), were considered in the present study, following Steneck and Dethier (1994).

Invasive potential

The impacts of an introduced species range from insignificant to extremely high and can be difficult to assess. Many organisms that enter a new or endangered area will not establish. Even species that do establish may not become a pest, or may initially have little impact, because the populations remain small (Mmaynard and Nowell 2009).

In this study, the International Union for Conservation of Nature's (IUCN 2002) definition of "invasive" was adopted, whereby an established species is considered to be an agent of ecological change and thus threatens native biological diversity. In addition, a species can be considered invasive if it causes economic damage or negative effects on human health (EPA 2001). Based on these premises, the invasive potential of each introduced species was derived from existing scientific literature and assigned to three categories: (1) no invasive potential, (2) unknown or (3) invasive potential (see Table 1).

\section{Date of First Record}

The first date of collection was used as the date of the first record. If this was not available, the date of the first written report was used instead (Supplemental Table 3).

\section{Results}

In the Azores archipelago, a total of 26 NIS of macroalgae were recorded (Supplemental Table 1), São Miguel Island with the highest number of NIS of macroalgae (18 species) and Corvo Island with the lowest number (2 species) (Supplemental Table 3). Along the archipelago, a total of 20 NIS of macroalgae appear to have established and 7 species have an invasive potential impact. Additionally, 40 species are identified as cryptogenic (Supplemental Table 2).
Table 2 Comparison between observed data and expected data $\left(\chi^{2}\right.$ test), based on the proportions between macroalgae species

\begin{tabular}{lrrr}
\hline & $\chi^{2}$ value & $D f$ & $P$ \\
\hline Global & & & \\
$\quad$ Total spp. versus NIS & 4.86 & 2 & 0.0900 \\
Global versus Azores & & & \\
$\quad$ Global spp. versus Azores (total) spp. & 0.99 & 2 & 0.9800 \\
$\quad$ Global NIS versus Azores NIS & 25.49 & 2 & $\mathbf{0 . 0 0 0 1}$ \\
Within Azores & & & \\
Native spp. versus NIS & 17.25 & 2 & $\mathbf{0 . 0 0 0 2}$ \\
$\quad$ Native spp. versus cryptogenic spp. & 0.10 & 2 & 0.9500 \\
Cryptogenic spp. versus NIS & 29.56 & 2 & $\mathbf{0 . 0 0 0 1}$ \\
\hline
\end{tabular}

Significance levels in bold

Origin (native, non-indigenous and cryptogenic species status)

The global occurrence of macroalgae species consists of $65 \%$ Rhodophyta, $16 \%$ Chlorophyta (Bryopsidophyceae, Dasycladophyceae, Siphonocladales and Ulvophyceae) and $19 \%$ Ochrophyta (Phaeophyceae) (Guiry 2012). This pattern is similar to the observed global pattern of NIS of macroalgae, $60 \%$ Rhodophyta, $24 \%$ Chlorophyta and $16 \%$ Ochrophyta (see Williams and Smith 2007, a global review which encompasses recently published reviews on seaweed introductions, case histories on specific species and regional reviews) (Table 2: global spp. vs. global NIS- $\left.\left(\chi^{2}-P<0.0900\right)\right)$.

In the Azores archipelago, about 439 species of marine macroalgae have been detected, of which $6 \%$ (26) are probably introduced (Supplemental Table 1, Azores NIS) and $9 \%$ (40) are considered cryptogenic (Supplemental Table 2, cryptogenic species). The percentage of global NIS macroalgae is $3 \%$, while this value is double in the Azores (6\%). The pattern of taxonomic distribution of NIS of macroalgae in the Azores includes $84 \%$ Rhodophyta, $8 \%$ Chlorophyta and $8 \%$ Ochrophyta. This Azores NIS pattern is significantly different from the known global taxonomic pattern $\left(\chi^{2}-P<0.0001\right)$, and it also contrasts with the native regional pattern of macroalgal species composition: $65 \%$ Rhodophyta, $17 \%$ Chlorophyta and $18 \%$ Ochrophyta (Table 2). The main difference is in the proportion of Rhodophyta.

The native origin of the 22 macroalgal NIS recorded in the Azores is the Indian and/or Pacific Oceans, while only three species originate from the western Atlantic and one species from the northeast Atlantic (Fig. 1). The majority of the Azores NIS of macroalgae belongs to the Rhodophyta phylum ( $84 \%$ ), and their native range does not seem to be a factor affecting their distribution (Fig. 2), although 


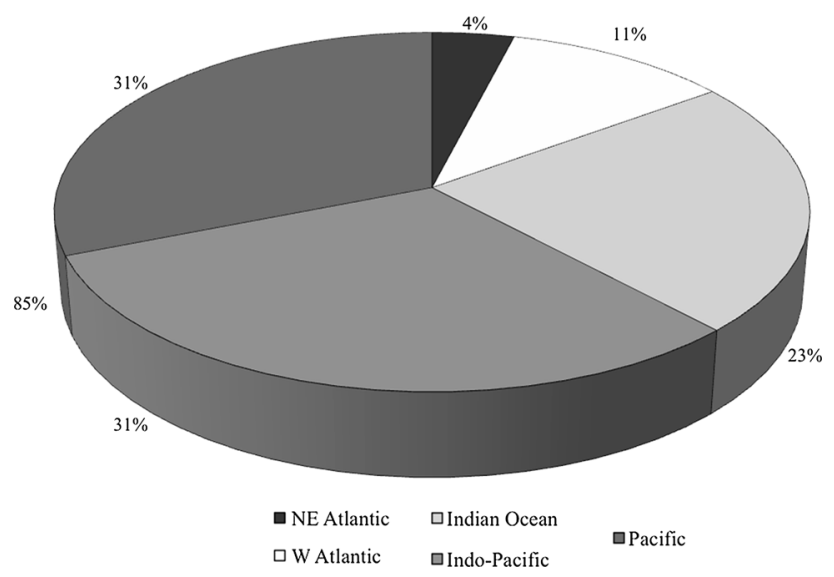

Fig. 1 Native range relative percentage of non-indigenous macroalgae in the Azores

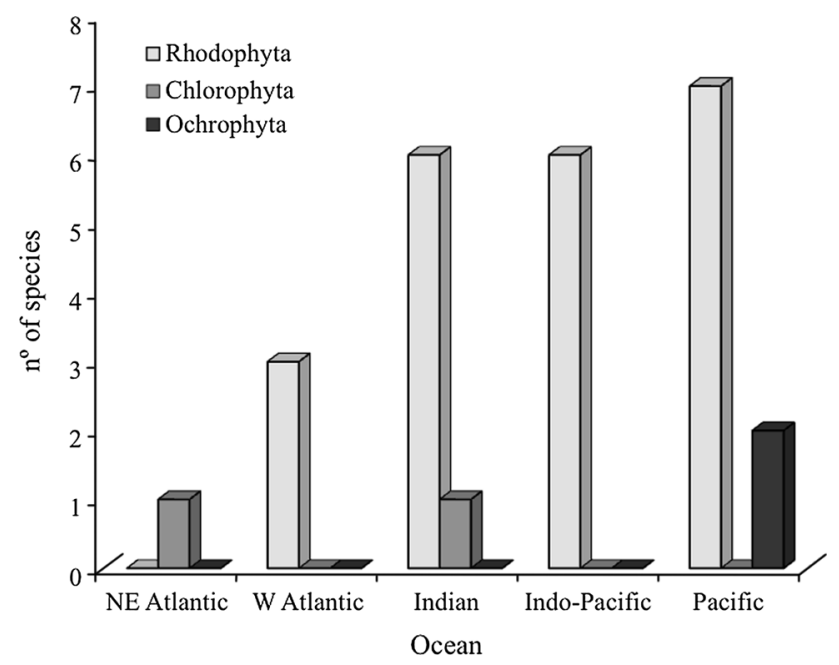

Fig. 2 Number of non-indigenous macroalgae in the Azores, presented by phylum

one exception was detected: Codium fragile ssp. fragile from the NE Atlantic belongs to the Chlorophyta (Fig. 2).

Among the 40 cryptogenic macroalgae, $64 \%$ are Rhodophyta, $18 \%$ are Chlorophyta and $18 \%$ are Ochrophyta, which is very similar to the Phyla proportion of the native regional pattern but contrasts with the regional pattern of NIS of macroalgae (Supplemental Table 2). This suggests that the majority of cryptogenic species may in fact be native (Table 2).

\section{Transportation vectors}

Maritime traffic seems to be the most prevalent vector for macroalgae introductions in the Azores, representing $69 \%$ of the introduced macroalgae, with hull fouling corresponding to at least $56 \%$ of this transportation vector.
There is a lack of information regarding the transportation vector for $31 \%$ of all macroalgal introductions (Fig. 3). There is no record of intentional introductions of macroalgae species in the Azores.

Population status (success of non-indigenous species) and density

From the 26 NIS macroalgae in the Azores, at least $77 \%$ seem to be established since they spread to more than one island (Fig. 3, Supplemental Table 3). These NIS exhibit the capacity to overcome abiotic factors and to adapt to a new niche. Relative densities are unknown for $55 \%$ of the established species (Fig. 3).

Functional group

Anatomical and morphological characteristics were determined for each non-indigenous algal species. Around $46 \%$ of all NIS are filamentous, and $38 \%$ are corticated, followed by siphonous ( $8 \%$ ), and finally foliose (4\%) and corticated foliose species (4\%). Within the Rhodophyta phylum, $55 \%$ of the introduced species are filamentous and all Chlorophyta are siphonous. Filamentous and corticated Rhodophyta is mainly transported in fouling communities (Fig. 4). Even among those macroalgae whose introduction vector is unknown, filamentous and corticated species are the most representative functional groups.

Invasive potential

Of the 20 established NIS of macroalgae, 7 are in the invasive category for their potential impact (Fig. 5). The species Asparagopsis armata, Asparagopsis taxiformis, Bonnemaisonia hamifera, Codium fragile subsp. fragile, Grateloupia turuturu and Symphyocladia marchantioides are established in the Azores and present on more than one island (Supplemental Table 3). Caulerpa webbiana is also established, has been recorded on only one island and is known as a successful invasive species in the Azores. An invasive potential was found in practically all foliose and siphonous species (Fig. 5). Most of the filamentous and corticated foliose NIS of the Azores has an unknown invasive potential.

\section{Discussion}

The NIS of macroalgae in the Azores showed a taxonomic composition pattern that is significantly different from the known global pattern. Rhodophyta was the dominant phylum of NIS macroalgae in the archipelago (84 \%). This pattern could be related to the ability to reproduce by 

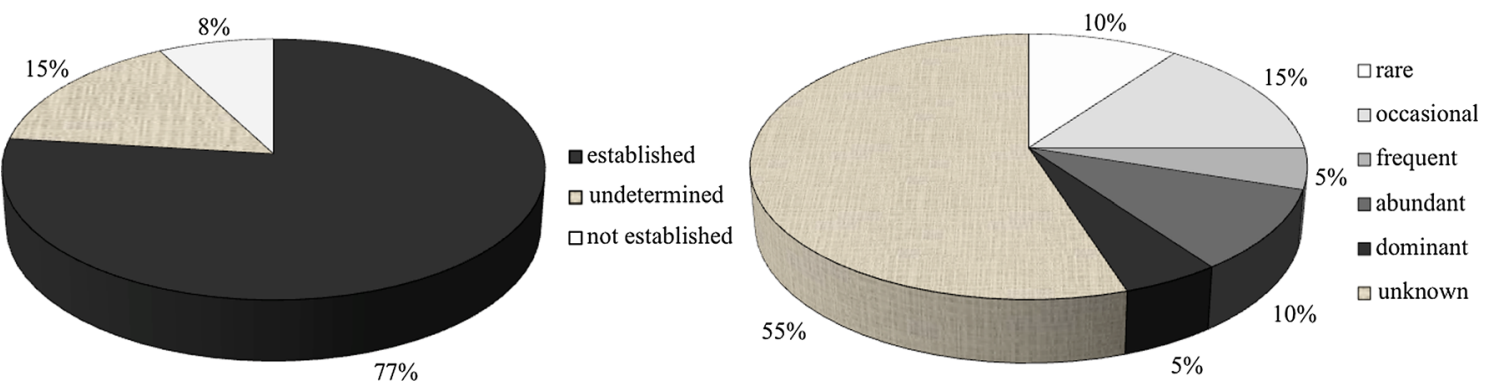

Fig. 3 Relative percentage of introduction success for non-indigenous macroalgae in the Azores and their relative densities, categorized using the DAFOR scale (Sutherland 2006)

Fig. 4 Number of nonindigenous macroalgae in the Azores, presented by functional group
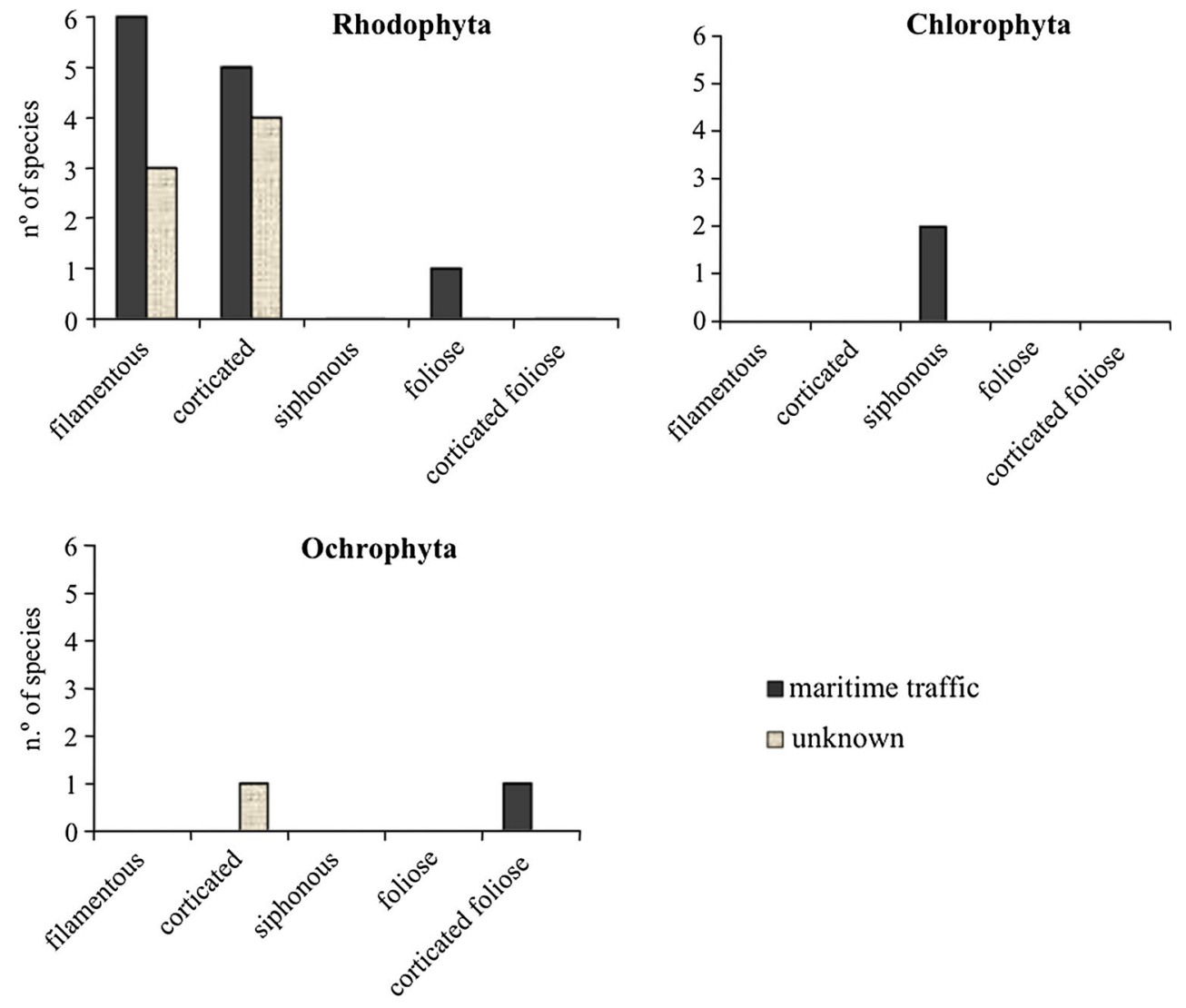

- maritime traffic

$\square$ unknown a

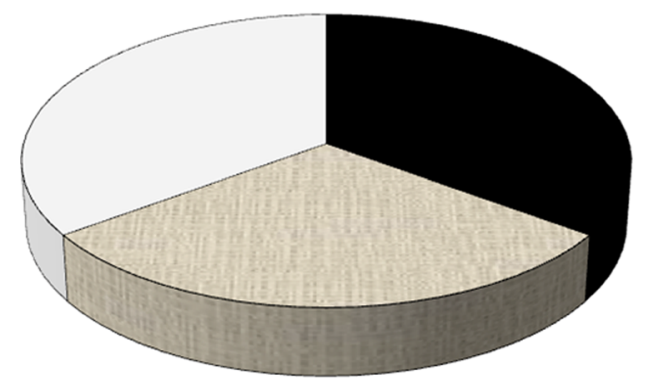

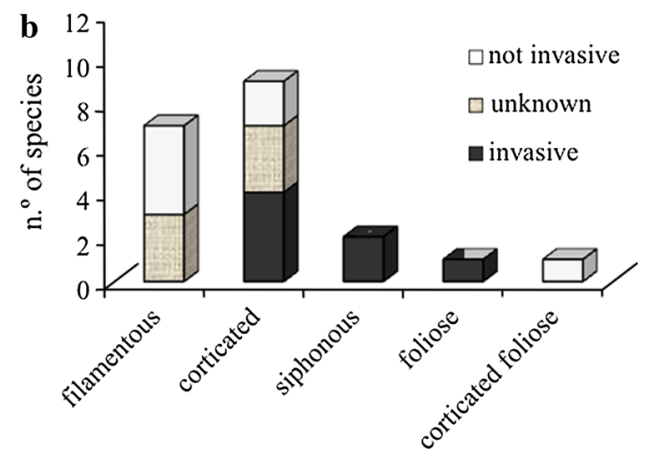

Fig. 5 Number of non-indigenous macroalgae in the Azores, presented by functional group and transportation vector 
fragmentation that is inherent to most species in this group (Williams and Smith 2007). Most NIS of macroalgae in the Azores were filamentous early colonizers, which are known to be found in disturbed environments such as harbors (Williams and Smith 2007). The corticated morphotype was also well represented among the NIS in the Azores and is characteristic of habitats with low physical disturbance (Steneck and Dethier 1994).

The Mediterranean Sea has been recognized as the region with the highest number of introduced species worldwide with 126 NIS macroalgae so far (Boudouresque and Verlaque 2005; Williams and Smith 2007) and including known NIS geographical areas such as the Thau Lagoon (Hérault, France-Mediterranean sea) with 45 species (Verlaque 2001) and the Italian coast with 33 species (Occhipinti et al. 2011). The NE Atlantic (the European Atlantic coasts) has about 76 NIS of macroalgae (Williams and Smith 2007). Australia so far counts 39 species, and other vast geographical areas such as the NE Pacific, the central Pacific and the NW Atlantic each account between 20 and 32 NIS of macroalgae (Williams and Smith 2007). The 26 NIS of macroalgae documented in the Azores are of particular relevance if one considers the small coastal extension of this region of about $844 \mathrm{~km}$ (Borges 2003), the narrow intertidal strip and the almost absent euphotic subtidal on these oceanic islands, characterized by cliffs lunging straight into the sea (Morton et al. 1998). As emphasized by Williams and Smith (2007), the documented patterns of macroalgal distribution observed in the different geographical areas of the globe may be related to the history of research and phycological expertise in a given region and may not correspond to the actual patterns of distribution. In the northern coast of continental Portugal, for example, in a coastal extension of approximately $250 \mathrm{~km}$ (one-third of the Azores coastal extension), 320 macroalgae are recorded. To the area in question, the number of NIS of macroalgae corresponds to $3 \%$ (see Aráujo et al. 2009), equivalent to the percentage of global NIS of macroalgae (Williams and Smith 2007). The high number of NIS of macroalgae observed in the Azores clearly contrasts with other geographical areas in the globe, and this phenomenon could indicate a vulnerability of oceanic islands to the introduction of species, enhanced by simplified trophic levels and a high availability of empty niches in islands' marine ecosystems.

The majority of successful introduced species in the Azores are native to the Indo-Pacific, an area containing the highest level of biodiversity for a number of different taxonomic groups, including macroalgae (Kerswell 2006; Williams and Smith 2007). This Indo-Pacific origin is similar to the native origin of NIS of macroalgae globally. Determining transportation vectors for NIS of macroalgae is difficult due to a lack of research focusing on this issue
(Occhipinti et al. 2011). Also, separating macroalgae from other groups is difficult since marine flora and fauna are usually grouped together in NIS studies. Nevertheless, depending on the geographical location, type of local industries, the availability of the history of introduction for a given species and the probability of marine entry vectors can be tracked back with confidence. Although $31 \%$ of macroalgae introductions have an unknown transportation vector in the Azores, there seem to be strong evidences that these species were indeed introduced. This idea has as a premise the characteristics suggested by Williams and Smith (2007) to explain the known global pattern of macroalgae introductions, e.g., discontinuous distribution in relation to the native range or introduced elsewhere in the European Atlantic coast.

In the Thau Lagoon, one of the hot spots of marine species introductions in Europe, the most probable vector of macroalgae introductions is aquaculture (through oyster transfers) (Verlaque 2001). The importance of this vector is re-enforced by the Mediterranean Sea data of Boudouresque and Verlaque (2005). However, the Azores are isolated oceanic islands with no significant aquaculture or aquarium trade, so the most likely entry vector for marine organisms is maritime traffic (passive transport on the hull, in ballast water or dry ballast, in or on cargo, on deck and on anchors). Moreover, as the Azores islands are more a "commercial products importation" region rather than a "commercial products exportation" one, meaning that ballast water generally is not discharged in Azores, the hull fouling pathway may be considered as the most likely dominating vector for macroalgae introductions in the Azores. The number of macroalgae NIS will probably increase in the near future due to the recent ban of tributyltin (TBT), the main active component in antifouling paints for vessels. Tributyltin has been discontinued and marked to be globally phased out by 2008 for environmental reasons (International Convention on the Control of Harmful Antifouling Systems on Ships 2012). The discontinuation of TBT is still not effective, as the stocks have not diminished; however, Schaffelke et al. (2006) predicted that the TBT ban, together with the marked increase in maritime traffic (type, speed, number and dimension of vessels), will contribute to a higher incidence of hull fouling, likely increasing at both the regional and global scale. To counteract this tendency, the International Maritime Organization (IMO) has developed several recommendations to address biofouling of ships and to minimize the transfer of aquatic species (IMO-MEPC62 2011).

Within the Azores archipelago, the first record of an introduced species has occurred in São Miguel island for $69 \%$ of the NIS of macroalgae. This is not surprising since São Miguel not only is the biggest and the main island of the archipelago, with higher maritime traffic movement, 
but also is located in the closest geographical group of the archipelago to the mainland. Faial, a known sailing stopover accounts with $15 \%$ of first records. Corvo, the smallest Island of the archipelago, almost $600 \mathrm{~km}$ apart from São Miguel has no first records of NIS of macroalgae and only accounts with $8 \%$ for the total Azores NIS of macroalgae. An intensive campaign should be developed along each island, employing the same sampling effort, in order to observe the development of these species within the Azores archipelago.

As emphasized by Occhipinti et al. (2011), the arrival of any NIS to a new biogeographical area has a significant ecological impact on the ecosystem by directly or indirectly affecting the different levels of biological organization, i.e., genetics, integrity of the organism, population, community and habitat/ecosystem, albeit the fact that in many cases the effects may be cryptic and go unnoticed (Carlton 2002). Invasive species may play a conspicuous role in the recipient ecosystem, becoming the dominant species or taking the place of keystone species, hence critically impacting the ecological balance of a given area. The impacts are reflected by changes in the diversity, biomass, structure and composition of communities, as well as by changes in food webs, primary production, nutrients cycles and disturbance regimes (Klein et al. 2005). Asparagopsis armata, Asparagopsis taxiformis, Bonnemaisonia hamifera, and Grateloupia turuturu are established and have been recorded on more than one island of the Azores. Since these species are included in a short list of the 100 worst NIS in the Mediterranean Sea (Streftaris and Zenetos 2006), special attention should be given to their populations in future studies and in local monitoring and mitigation programs, in order to avoid long-term negative ecological impacts.

The study of introduced species in the terrestrial environment produced the generalized "tens rule" (Williamson and Fitter 1996), i.e., on average, $10 \%$ of arriving species will settle upon arrival to a given region, $10 \%$ of these will established and $10 \%$ of the introduced species will become invasive. Invasive macrophytes introduced to the Mediterranean Sea fit well with Williamson and Fitter's "tens rule" according to Boudouresque and Verlaque (2002). In the Azores, from 26 recorded NIS of macroalgae, $77 \%$ have established, i.e., far more than $10 \%$. It is likely that the actual number of introduced species that tried to settle in the Azores is underestimated or the empty niches characteristic of oceanic islands allows for increased establishment success. Of 20 known established NIS of macroalgae, only one has been proven to be invasive, Caulerpa webbiana. Since its arrival to the Faial Island, this alga has rapidly colonized and dominated the marine bottom, forming mono-species stands in the main harbor of the island, as well as surrounding areas (Amat et al. 2008).
Nevertheless, given the high numbers of recent new species with invasive potential and of cryptogenic species found in the Azores, it must be expected that the current scenario of invasion and dispersion will become even more accentuated. Moreover, because ship hull fouling is the most relevant vector for NIS of macroalgae in the Azores, and given that there is a large variety of possible species with a potential to arrive in the region (both small species and large species whose life history may include a microscopic or small phase), the present study unveils the urgent need of regulation and development of preventive measures to accurately monitor this problematic transportation vector and reinforcing the importance of following the IMO guidelines for the control and management of ships' Biofouling to minimize the transfer of invasive aquatic species (IMO-MEPC62 2011).

The uniqueness of oceanic islands is in part represented by the simplicity of their ecosystems, with typically fewer species per unit area than on the mainland (Whittaker 1998). Also, individual traits such as dispersal capacity, invasive behavior and reproductive output tend to be lower with island species (Whittaker 1998) and may translate into an ecological vulnerability to introduced species. The environmental specificity of insular marine ecosystems, where millions of years of physical isolation have favored the evolution of unique species and habitats, can be easily jeopardized by an increasing number of invasives, threatening native species and even driving some to local extinction.

The authors consider that the approach presented in this work is fundamentally important and should be applied to other oceanic archipelagos in order to discriminate routes of entry and understand the taxonomic distribution pattern of oceanic island macroalgae. Specially, if the different NIS taxonomic pattern of macroalgae observed on the Azores is identical to other similarly isolated archipelagos in the globe, it will corroborate this observed contrast in macroalgae distribution between oceanic archipelagos and global distributions.

Acknowledgments The authors are grateful to Dr. Pedro Rodrigues, Dr. José Marcelino and two anonymous referees for providing helpful comments to improve earlier versions of this manuscript and to Dr. Ian Dodkins for English revision. This project was funded by the Direcção Regional de Ciência e Tecnologia (DRCT)— “Açores: Stopover for Marine Aliens Species?”-ASMAS-M2.1.2/I/032/2011.

\section{References}

Amat JN, Cardigos F, Serrão-Santos R (2008) The recent northern introduction of the seaweed Caulerpa webbiana (Caulerpales, Chlorophyta) in Faial, Azores Islands (North-Eastern Atlantic). Aquat Invasions 3(4):417-422 
Aráujo R, Bárbara I, Tibaldo M, Berecibar E, Díaz Tapia P, Pereira R, Santos R, Sousa-Pinto I (2009) Checklist of benthic marine algae and cyanobacteria of northern Portugal. Bot Mar 52:24-46

Ardré F, Boudouresque C-F, Cabio'h J (1974) Présence remarquable du Symphyocladia marchantioides (Harvey) Falkenberg (Rhodomélacéns, Céramiales) aux Açores. B Soc Phyc Fr 19:179-183

Athanasiadis A, Tittley I (1994) Antithamnioid algae (Rhodophyta, Ceramiaceae) newly recorded from the Azores. Phycologia 33:77-80

Bashmachnikov I, Lafon V, Martins A (2004) Sea surface temperature distribution in the Azores region. Part II: space-time variability and underlying mechanisms. Arquipelago 21A:19-32

Borges P (2003) Ambientes litorais nos grupos Central e Oriental do arquipélago dos Açores. conteúdos e dinâmica de microescala. $\mathrm{PhD}$ thesis, Departamento Geociências, Universidade dos Açores, Portugal

Botelho A, Dionisio MA, Cunha A, Torres P, Monteiro S, Geraldes D, Hipólito C, Parente M, Angélico MM, Costa AC (2010) Contributo para a Inventariação da Biodiversidade Marinha da Ilha de Santa Maria. Relatórios e Comunicações do Departamento de Biologia da Universidade dos Açores 36:75-87

Boudouresque CF, Verlaque M (2002) Biological pollution in the Mediterranean Sea: invasive versus introduced macrophytes. Mar Pollut Bull 44:32-38

Boudouresque CF, Verlaque M (2005) Nature conservation, Marine Protected Areas, suitable development and the flow of invasive species to the Mediterranean Sea. TR Scient Parc Nat de PortCros 21:29-54 Bridgwood S (2010) Codium fragile ssp. fragile (Suringar) Hariot summary document. Fisheries Research Report No. 202. Department of Fisheries, Western Australia

Bullock RC, Turner RD, Fralick RA (1990) Species richness and diversity of algal-associated micromolluscan communities from São Miguel Açores. Açoreana 1990:39-58

Cardigos F, Tempera F, Ávila S, Gonçalves J, Colaço A, Santos RS (2006) Non-indigenous marine species of the Azores. Helgoland Mar Res 60:160-169

Carlton JT (1985) Transoceanic and interoceanic dispersal of coastal marine organisms: the biology of ballast water. Oceanogr Mar Biol 23:313-371

Carlton JT (1996) Biological invasions and cryptogenic species. Ecology 77(6):1653-1655

Carlton JT (2002) Bioinvision ecology: assessing invasion impact and scale. In: Leppäkoski E, Gollasch S, Olenin S (eds) Invasive aquatic species of Europe - distribution, impacts and management. Kluwer, Dordrecht, Boston, London, pp 7-19

Castilla JC, Uribe M, Bahamonde N, Clarke M, DesqueyrouxFaundez R, Kong I, Moyano H, Rozbaczylo N, Santelices B, Valdovinos C, Zavala P (2005) Down under the southeastern Pacific: marine nonindigenous species in Chile. Biol Invasions 7:213-232

Castro ML, Viegas MC (1987) Contribuição para o estudo da zona intertidal (substrato rochoso) da ilha de SãoMiguel-Açores. Fácies de Corallina elongata Ellis \& Solander. Resultados preliminares. Cuadernos Marisqueros 11:59-69

Chapman AS, Scheibling RE, Chapman ARO (2002) Species introductions and changes in the marine vegetation of Atlantic Canada. In: Claudi R, Nantel P, Muckle-Jeffs E (eds) Alien invaders in Canada's waters, wetlands and forests. Natural Resources Canada, Canadian Forest Service, Ottawa, pp 133-148

CIESM (2002) Alien marine organisms introduced by ships in the Mediterranean and Black seas. CIESM Workshop Monographs $\mathrm{n}{ }^{\circ}$ 20, Monaco. http://www.ciesm.org/online/monographs/Istan bul.pdf. Accessed 21 June 2013

Coutinho R, Pacheco J, Wallenstein N, Pimentel A, Marques R, Silva $R$ (2009) Integrating geological knowledge in planning methods for small islands coastal plans. J Coastal Res 56:1199-1203
DAISIE (2009) Handbook of Alien species in Europe. Springer, Berlin

Dionísio MA, Micael J, Parente MI, Norberto R, Cunha A, Brum JMM, Cunha L, Lopes C, Monteiro S, Palmero AM, Costa AC (2008) Contributo para o conhecimento da biodiversidade marinha da ilha das Flores. Relatórios e Comunicações do Departamento de Biologia da Universidade dos Açores 35:65-84

Dizerbo AH, Herpe E (2007) Liste et répartition des algues marines des côtes françaises de la Manche et de l'Atlantique. Iles Normandes incluses, Éditions Anaximandre, Landernau

Eno NC, Clark RA, Sanderson WG (eds) (1997) Nonnative marine species in British waters: a review and directory. JNCC, Peterborough

EPA-United States Environmental Protection Agency (2001) Aquatic nuisance species. Annual Report http://www.epa.gov/gmpo/ nonindig.html

Farnham WF (1980) Studies on aliens in the marine flora of southern England. In: Price JH, Irvine DEG, Farnham WF (eds) The shore environment, volume 2: ecosystems. Academic Press, London, pp 875-914

Feldmann J, Feldmann G (1942) Récherches sur les Bonnemaisoniacées et leur alternances de générations. Ann Sci Naturelle (Botanie) Sér II 3:75-175

Fralick RA, Hehre EJ (1990) Observations on the marine algal flora of the Azores II: an annotated checklist of the Chlorophyta from the Azores. Arquipelago 8:11-17

Fralick RA, Hehre EJ, Mathieson AC (1985) Observations of the marine algal flora of the Azores 1: notes on the epizoic algae occurring on the marine mollusks Patella spp. Arquipelago 6:39-43

França Z, Cruz JV, Nunes JC, Forjaz VH (2003) Geologia dos Açores: uma perspectiva actual. Açoreana 10(1):11-14

Fredericq S, Serrao E, Norris JN (1992) New records of marine red algae from the Azores. Arquipelago 10:1-4

Gain L (1914) Algues provenant des campagnes de "1'Hirondelle II" (1911-1912). Bull lnst Ocianogr 279:1-23

Galil BS (2009) Taking stock: inventory of alien species in the Mediterranean sea. Biol Invasions 11:359-372

Gavio B, Fredericq S (2002) Grateloupia turuturu (Halymeniaceae, Rhodophyta) is the correct name of the non-native species in the Atlantic known as Grateloupia doryphora. Eur J Phycol 37:349-360

Godwin LS (2001) Hull fouling of maritime vessels as a pathway for marine species invasions to the Hawaiian Islands. In Proceedings of the 24th meeting of the marine facilities panel of the United States Japan Cooperative Program in Natural Resources, November 4-10:1-10

Goulletquer P, Bachelet G, Sauriau PG, Noël P (2002) Open Atlantic coast of Europe-A century of introduced species into French waters. In: Leppäkoski E, Gollash S, Olenin S (eds) Invasive aquatic species of Europe. Distribution, impacts and management. Kluwer Academic Publishers, Dordrecht, pp 276-290

Guiry MD (2012) How many species of algae are there? J Phycol 48:1057-1063

HELCOM (2008) List of non-indigenous, cryptogenic and harmful native species in the Baltic sea and HELCOM Target Species List (Version 2)

Hewitt CL, Campbell ML, Thresher RE, Martin RB, Boyd S, Cohen BF, Currie DR, Gomon MF, Keough MJ, Lewis JA, Lockett MM, Mays N, McArthur MA, O'Hara TD, Poore GCB, Ross DJ, Storey MJ, Watson JE, Wilson RS (2004) Introduced and cryptogenic species in Port Phillip Bay, Victoria, Australia. Mar Biol 144:183-202

ICES (2007) Status of introductions of non-indigenous marine species to the North Atlantic and adjacent waters 1992-2002. ICES Cooperative Research Report No. 284 
IMO-MEPC62 (2011) Marine Environment Protection Committee (MEPC) - 62nd session: 11 to 15 July 2011. International Maritime organization. http://www.imo.org/MediaCentre/Meet ingSummaries/MEPC/Pages/MEPC-62nd-session.aspx. Accessed 20 January 2014

IUCN (2000) International Union for Conservation of Nature. Guidelines for the prevention of biodiversity loss caused by alien invasive species. IUCN Council, Gland Switzerland

IUCN (2002) International Union for Conservation of Nature. Policy recommendations Papers for Sixth meeting of the Conference of the Parties to the Convention on Biological Diversity (COP6). The Hague, Netherlands, http://www.iucn.org/themes/pbia/wl/ docs/biodiversity/cop6/invasives.doc

Jacoby C, Lapointe BE, Creswell L (2004) Are native and nonindigenous seaweeds overgrowing Florida's east coast reefs? Florida Sea Grant College Program. SGEF-156. http://flseagrant.org/ program areas/coastal habitats/publications/SGEF 156 web.pdf. Accessed 3 July 2013

Jousson O, Pawlowski J, Zaninetti L, Zechman FW, Dini F, Di Guiseppe G, Woodfield R, Millar A, Meinesz A (2000) Invasive alga reaches California. Nature 408:157-158

Kerswell AP (2006) Global biodiversity patterns of benthic marine algae. Ecology 87:2479-2488

Klein J, Ruitton S, Verlaque M, Boudouresque C-F (2005) Species introductions, diversity and disturbances in marine macrophyte assemblages of the northwestern Mediterranean Sea. Mar EcolProg Ser 290:79-88

Larkum AW (1960) Botany (Algae). Azores expedition 1959, Final Report. Imperial College of Science and Technology, London, pp 120-127

Lazaridou E (1994) Systematics bionomy and ecological study of the marine phytobenthos of the Milos Island (Cyclades). Ph.D. thesis, Aristotle University of Thessaloniki.

León-Cisneros K, Tittley I, Terra MR, Nogueira EM, Neto AI (2012) The marine algal (seaweed) flora of the Azores: 4, further additions. Arquipelago 29:25-32

Lewis JA (1999) A review of the occurrence of exotic macroalgae in Southern Australia, with emphasis on Port Phillip Bay, Victoria. In: Hewitt CL, Campbell ML, Tresher RE, Martin RB (eds) Marine Biological Invasions of Port Phillip Bay, Victoria. Centre for Research on Introduced Marine Pests Technical report No. 20. CSIRO Mar Res, Hobart, pp 61-87

Mathieson AC, Dawes CJ, Pederson J, Gladych RA, Carlton JT (2008) The Asian red seaweed Grateloupia turuturu (Rhodophyta) invades the Gulf of Maine. Biol Invasions 10:985-988

Maynard G, Nowell D (2009) Biosecurity and quarantine for preventing invasive species. In: Clout MN, Williams PA (eds) Invasive species management-A handbook of principles and techniques. Oxford University Press, Oxford, pp 1-18

McCulloch BR, Stewart KW (1998) Range extension and new locality records for the stonecat, Noturus flavus, in Manitoba: evidence for a recent natural invasion. Can Field-Nat 112(2):217-224

Miller AK, Aguilar-Rosas LE, Pedroche FF (2011) A review of nonnative seaweeds from California, USA and Baja California, Mexico. Hidrobiologica 21(3):365-379

Minchin D (2007) A checklist of alien and cryptogenic aquatic species in Ireland. Aquat Invasions 2(4):341-366

Montagne C (1837) Centurie de plantes cellulaires exotiques nouvelles. Ann Sci Naturelle (Botanie) Sér VIII: 345-370

Morton B, Britton JC, Frias Martins AM (1998) "Ecologia Costeira dos Açores”. Sociedade Afonso Chaves, São Miguel, Açores, Portugal. ISBN: 972-97774-1-1

Nelson WA (1999) A revised checklist of marine algae naturalised in New Zealand. NZ J Bot 37:355-359
Neto AI (1989) Algas marinhas do litoral da ilha Graciosa. Graciosa/ 88. Relatório preliminar. Relatórios e Comunicações do Departamento de Biologia da Universidade dos Açores 17:61-65

Neto AI (1991) Zonação litoral de dois locais da ilha de São Miguel (Açores) e estudo dos seus povoarnentos fitobent6nicos. Universidade dos Açores, Ponta Delgada, Provas de Aptidão Pedagógica e Capacidade Cientifica

Neto IA (1997) Studies on algal communities of São Miguel, Azores. $\mathrm{PhD}$ thesis. Universidade dos Açores, Ponta Delgada

Neto IA, Azevedo JMN (1990) Contribuição para o estudo dos padrões de zonação litoral da Ilha das Flores. Relatórios e Comunicações do Departamento de Biologia da Universidade dos Açores 18:89-102

Neto AI, Baldwin HP (1990) Algas marinhas do litoral das ilhas do Corvo e Flores. Relatórios e Comunicações do Departamento de Biologia da Universidade dos Açores 18:103-111

Neto AI, Fralick RA, Baldwin HP, Hehre EJ (1991) Algas marinhas do litoral de Santa Maria. Relatórios e Comunicações do Departamento de Biologia da Universidade dos Açores 19:33-42

Nyberg C, Wallentinus I (2005) Can species traits be used to predict marine macroalgal introductions? Biol Invasions 7:265-279

Occhipinti A, Marchini A, Cantone G, Castelli A, Chimenz C, Cormaci M, Froglia C, Furnari G, Gambi MC, Giaccone G, Giangrande A, Gravili C, Mastrototaro F, Mazziotti C, OrsiRelini L, Piraino S (2011) Alien species along the Italian coasts: an overview. Biol Invasions 13:215-237

Parente MI (2010) List of the marine macroalgae (Rhodophyta, Chlorophyta, Phaeophyceae). In: Borges PAV, Costa A, Cunha R, Gabriel R, Gonçalves V, Martins AF, Melo I, Parente M, Raposeiro P, Rodrigues P, Santos RS, Silva L, Vieira P, Vieira V (eds) A list of the terrestrial and marine biota from the Azores. Princípia, Cascais, pp 9-33

Parente MI, Gil-Rodríguez MC, Haroun RJ, Neto AI, De Smedt G, Hernández-González CL, Berecibar Zugasti E (2001) Flora marina de las islas Salvajes: resultados preliminares de la campaña 'Macaronesia 2000. Revista de la Academia Canarina de Ciencias 12(3-4):9-20

Pearson DE (2009) Biological invasions on oceanic islands: implications for island ecosystems and avifauna. In: Chae HY, Choi CY, Nam HY (eds) Seabirds in danger: Invasive species and conservation of island ecosystem. Proceeding 3rd international symposium on migratory birds - 25 September 2009, Mokpo. National Park Migratory Birds Center, Korea, pp 3-16

Piccone A (1889) Alghe della crociera del "Corsaro" all Azzorre. Nuovo Giornnale Botanico Italiano 21(2):171-214

Pollard DA, Hutchings PA (1990) A review of exotic marine organisms introduced into the Australian region. II. Invertebrates and algae. Asian Fish Sci 3:223-250

Pryor J (1967) Intertidal marine algae of São Jorge. Chelsea College Azores Expedition. 1965. Final Report, London, pp 17-30

Ramos E, Juanes JA, Galván C, Neto JM, Melo R, Pedersen A, Scanlan C, Wilkes R, van den Bergh E, Blomqvist M, Karup H P, Heiber W, Reitsma JM, Ximenes MC, Silió A, Méndez F, González B (2012) Coastal waters classification based on physical attributes along the NE Atlantic region. An approach for rocky macroalgae potential distribution. Estuar Coast Shelf S, doi:10.1016/j.ecss.2011.11.041

Ribera-Siguan MA (2002) Review of non-native marine plants in the Mediterranean Sea. In: Leppä koski E, Gollasch S, Olenin S (eds) Invasive aquatic species of Europe. Distribution, impacts and management. Kluwer Academic Publishers, Dordrecht, pp 291-310

Rilov G, Crooks JA (2009) Biological invasions in marine ecosystems-ecological, management, and geographic perspectives. Springer, Berlin 
Rosas-Alquicira EF, Riosmena-Rodríguez R, Neto AI (2011) Segregating characters used within Amphiroa (Corallinales, Rhodophyta) and taxonomic reevaluation of the genus in the Azores. J Appl Phycol 23(3):475-488

Rosenthal H (1980) Implications of transplantations to aquaculture and ecosystems. Mar Fish Rev 42:1-14

Rueness J, Heggøy E, Husa V, Sjøtun K (2007) First report of the Japanese red alga Antithamnion nipponicum (Ceramiales, Rhodophyta) in Norway, an invasive species new to northern Europe. Aquat Invasions 2(4):431-434

Ruiz GM, Hewitt CL (2008) "Latitudinal Patterns of Biological Invasions in Marine Ecosystems: A Polar Perspective. In: Krupnik I, Lang MA, Miller SE (eds) Smithsonian at the poles: contributions to international polar year science. Smithsonian Institution Scholarly Press, Washington DC, pp 347-358

Ruiz GM, Fofonoff PW, Carlton JT, Wonham MJ, Hines AH (2000) Invasion of coastal marine communities in North America: apparent patterns, processes, and biases. Annu Rev Ecol Syst 31:481-531

Sansón M (1994) Notes on Ceramiaceae (Rhodophyta) from the Canary Islands: new Records and observations on morphology and geographical distribution. Bot Mar 37:347-356

Schaffelke B, Hewitt CL, Smith JE (2006) Introduced macroalgae - a growing concern. J Appl Physiol 18:529-541

Schmidt OC (1929) Beiträge zur Kenntnis der Meeresalgen der Azoren II. Hedwigia 69:165-172

Schmidt OC (1931) Die marine vegetation der Azoren in Ihren Grundzügen Dargestellt. Bibliotheca Botanica 24(102):1-116

Skoufas G, Tsirika A (2003) Preliminary results of the epibiotic flora on Eunicella singularis (Gorgonacea) colonies from the north Aegean Sea. In: Proceedings of the second mediterranean symposium on marine vegetation, Athens, pp 244

Smith JE, Hunter CL, Smith CM (2002) Distribution and reproductive characteristics of nonindigenous and invasive marine algae in the Hawaiian Islands. Pac Sci 56:299-315

South GR, Tittley I (1986) A checklist and distributional index of the benthic marine algae of the North Atlantic Ocean. Huntsman Marine Laboratory and British Museum (Natural History), St. Andrews and London

Steneck RS, Dethier MN (1994) A functional group approach to the structure of algal dominated communities. Oikos 69:476-498

Stone CP, Smith CW, Tunison JT (1992) Alien plant invasions in native ecosystems of Hawaii: management and research. University of Hawaii Press, Honolulu

Streftaris N, Zenetos A (2006) Alien marine species in the Mediterranean-the 100 'worst invasives' and their impact. MediterrMar Sci 7(1):87-118

Streftaris N, Zenetos A, Papathanassiou E (2005) Globalisation in marine ecosystems - The story of non-indigenous marine species across European Seas. Oceanogr Mar Biol 43:419-453

Sutherland WJ (2006) Ecological census techniques: a handbook, 2nd edn. Cambridge University Press, Cambridge

Thomsen MS, Wernberg T, Stææhr P, Krause-Jensen D, RisgaardPetersen N, Silliman BR (2007) Alien macroalgae in Denmarka broad-scale national perspective. Mar Biol Res 3(2):61-72

Tittley I, Neto AI (1994) Expedition Azores 1989: benthic marine algae (seaweeds) recorded from Faial and Pico. Arquipelago 12A:1-13

Tittley I, Neto AI (2005) The marine algal (seaweed) flora of the Azores: additions and amendments. Bot Mar 48:248-255

Tittley I, Neto AI, Farnham WF, Parente MI (2001) Additions to the marine algal (seaweed) flora of the Azores. Bot Mar 44:215-220

Tittley I, Neto AI, Parente MI (2009) The marine algal (seaweed) flora of the Azores: additions and amendments 3. Bot Mar $52: 7-14$
Torres P, Lopes C, Dionísio MA, Costa AC (2010) Espécies exóticas invasoras marinhas da ilha de Santa Maria, Açores. Relatórios e Comunicações do Departamento de Biologia da Universidade dos Açores 36:103-111

Trelease W (1897) Botanical observations on the Azores. Eighth Annual Report of the Missouri Botanical Garden 76-213

Trowbridge CD (1998) Ecology of the green macroalga Codium fragile (Suringar) Hariot 1889; invasive and non-invasive subspecies. Oceanogr Mar Biol 36:1-64

Tsiamis K, Panayotidis P (2007) First record of Asparagopsis taxiformis (Delile) Trevisan de Saint-Léon (Rhodophyta: Florideophyceae: Bonnemaisoniales: Bonnemaisoniaceae) in Greece. Aquat Invasions 2(4):435-438

Tsiamis K, Panayotidis P, Zenetos A (2008) Alien marine macrophytes in Greece: a review. Bot Mar 51:237-246

Verlaque M (1994) Inventaire des palntes introduites en Mediterranee: origine et repercussion sur l'environement et les activites humaines. Oceanol Acta 17(1):1-23

Verlaque M (2001) Checklist of the macroalgae of Thau Lagoon (Herault, France), a hot spot of marine species introduction in Europe. Oceanol Acta 24:29-49

Verlaque M, Riouall R (1989) Introduction de Polysiphonia nigrescens et d'Antithamnion nipponicum (Rhodophyta, Ceramiales) sur le littoral méditerranéen français. Cryptogamie Algol 10:313-323

Vitousek PM (1990) Biological invasions and ecosystem processes: towards an integration of population biology and ecosystem studies. Oikos 57:7-13

Wallenstein FM (2011) Rocky Shore Macroalgae Communities of the Azores (Portugal) and the British Isles: a Comparison for the Development of Ecological Quality Assessment Tools. PhD thesis, School of Life Sciences, Heriot-Watt University, Edinburgh, Scotland, UK

Wallenstein FM, Neto AI (2006) Intertidal rocky shore biotopes of the Azores: a quantitative approach. Helgoland Mar Res 60:196-206

Wallenstein FM, Peres SD, Xavier ED, Neto AI (2010) Phytobenthic communities of intertidal rock pools in the eastern islands of Azores and their relation to position on shore and pool morphology. Arquipelago 27:9-20

Wallentinus I (2002) Introduced marine algae and vascular plants in European aquatic environments. In: Leppakoski E, Gollasch S, Olenin S (eds) Invasive aquatic species of Europe-distribution impacts and management. Kluwer Academic Publishers, London, pp 27-52

Whittaker RJ (1998) Island biogeography: ecology, evolution and conservation. Oxford University Press, Oxford

Williams SL, Smith JE (2007) A global review of the distribution, taxonomy, and impacts of introduced seaweeds. Ann Rev Ecol Evol Syst 38:327-359

Williamson M, Fitter A (1996) The varying success of invaders. Ecology 77:1661-1666

Wonham MJ, Carlton JT (2005) Trends in marine biological invasions at local and regional scales: the Northeast Pacific Ocean as a model system. Biol Invasions 7:369-392

Yoneshigue Y (1985) Taxonomie et ecologie des algues marines dans la region de Cabo Frio (Rio de Janeiro, Brasil). PhD Thesis. Université d'Aix Marseille II, France

Zenetos A, Gofas S, Verlaque M, Cinar ME, GarcÍa Raso JE, Bianchi CN, Morri C, Azzurro E, Bilecenoglu M, Froglia C, Siokou I, Violanti D, Sfriso A, San Martín G, Giangrande A, Katagan T, Ballesteros E, Ramos-Espla' A, Mastrototaro F, Ocaña O, Zingone A, Gambi MC, Streftaris N (2010) Alien species in the Mediterranean Sea by 2010. A contribution to the application of European Union's Marine Strategy Framework Directive (MSFD). Part I. Spatial distribution. Mediterr Mar Sci 11(1):381-493 